\title{
The Association Between HLA Class II Alleles and the Occurrence of Factor VIII Inhibitor in Thai Patients with Hemophilia A
}

\author{
Tayland'lı Hemofili A Hastalarında, HLA Sinıf II Alleleri ve \\ Faktör VIII İnhibitör Oluşumunun İlişkisi
}

\author{
Oytip Nathalang ${ }^{1}$, Pramote Sriwanitchrak ${ }^{1}$, Werasak Sasanakul ${ }^{2}$, Ampaiwan Chuansumrit ${ }^{2}$ \\ ${ }^{1}$ Thammasat University, Faculty of Allied Health Sciences, Department of Medical Technology, Pathumtani, Thailand \\ ${ }^{2}$ Mahidol University, Faculty of Medicine, Ramathibodi Hospital, Department of Pediatrics, Bangkok, Thailand
}

\begin{abstract}
Objective: This study aimed to investigate the association between HLA class II alleles and the occurrence of FVIII inhibitor in Thai hemophilia A patients.

Material and Methods: The distribution of HLA-DRB1 alleles and DQB1 alleles in 57 Thai hemophilia A patients and 36 blood donors as controls was determined using the PCR sequence-specific primer (PCR-SSP) method, and the association between the occurrence of factor VIII (FVIII) inhibitor and the presence of certain HLA class II alleles was investigated.

Results: The frequency of HLA-DRB1*15 was higher in the hemophilia A patients with and without FVIII inhibitor, whereas that of DRB1*14, DRB1*07, and DQB1*02 was lower in the hemophilia A patients with FVIII inhibitor, as compared to controls. Interestingly, only the frequency of DRB $1 * 15$ was significantly higher in the patients with inhibitor than in the controls $(P=0.021)$. Moreover, the frequency of $D R B 1 * 15$ in the patients with inhibitor was higher than in those without inhibitor $(P=0.198)$.
\end{abstract}

Conclusion: The study's findings show that the DRB1*15 allele might have contributed to the occurrence of inhibitor in the Thai hemophilia A patients; however, additional research using larger samples and high-resolution DRB1 typing is warranted.

Key Words: HLA class II alleles, FVIII inhibitor, Hemophilia A, Thais

Özet

Amaç: Bu çalışmada HLA sınıf II allelleri hemofili A ile Tayland'lı hastalarda FVIII inhibitörü oluşumu ile ilişkiyi araştırmaktır.

Gereç ve Yöntemler: Hemofili 57 Tayland'ı hastalarda HLA-DRB1 allelleri ve DQB1 allel dağılımı bir PCR-sıra özel astar (PCR-SSP) yöntemi ve faktör VIII (FVIII) inhibitör oluşumu arasındaki ilişki kullanılarak belirlendi ve bazı HLA klas II allelleri varlığı araştırılmıştır.

Address for Correspondence: Ampaiwan CHUANSUMRIT, M.D.,

Department of Pediatrics, Faculty of Medicine, Ramathibodi Hospital, Mahidol University, Rama VI Road, Bangkok, 10400, Thailand

Phone: +90662 2011749 E-mail: raajs@mahidol.ac.th

Received/Gelis tarihi : June 29, 2011

Accepted/Kabul tarihi : September 19, 2011 
Bulgular: HLA-DRB1 sıklığ * 15 ve FVIII inhibitörü olmayan iki hemofili hastalarında artmış iken DRB1 olanlar * 14, DRB1 * 07 ve DQB1 * 02 FVIII inhibitörleri ile hemofili hastalarında azalmıştı. İlginçtir, sadece DRB1 * 15 önemli kontrol $(P=0.021)$ ile karşılaştırıldığında inhibitörleri olan hastalarda artmıştır. Ayrıca, inhibitörü olan hastalarda DRB1 * 15 frekans olmayan inhibitörü $(P=0.198)$ olan hastalarda daha yüksek olma eğiliminde.

Sonuç: Bulgularımız DRB1 * 15 allel Tay hemofili A hastalarında inhibitör oluşumuna katkıda bulunabileceğini göstermiştir. Ancak, daha büyük bir örneklem büyüklügü ve yüksek çözünürlüklü DRB1 yazarak garantilidir.

Anahtar Sözcükler: HLA klas II allelleri, FVIII inhibitörü, Hemofili A, Thais

\section{Introduction}

One of the most serious complications in patients with hemophilia $\mathrm{A}$ is the occurrence of an inhibitor frequently, IgG4 antibodies directed against epitopes in factor VIII (FVIII). This may be induced by replacement of the missing factor via cryoprecipitate or FVIII concentrate administration. The antibody attached to FVIII will neutralize or inhibit its ability to stop bleeding. FVIII inhibitor is usually detected in one of two ways. First, the inhibitor may be discovered in asymptomatic patients via routine screening performed during a comprehensive clinical examination. Second, an inhibitor may be detected when bleeding is suddenly and unexpectedly unresponsive to treatment with FVIII. Generally, the incidence of FVIII inhibitor in hemophilia A patients with severe disease (FVIII:C < 1\%) and moderate disease (FVIII:C $>1 \%$ to $5 \%$ ) is estimated to be $20 \%$ and $33 \%$, respectively [1-6]; however, differences in the incidence between ethnic groups might be due to genetic differences. Moreover, the lack of recognition is one of the causes of low incidence of inhibitor in economically less-developed countries.

It has been reported that molecular defects in the factor VIII gene and the major histocompatibility complex molecules, especially HLA class II alleles, are associated with antibody formation. An increased occurrence of FVIII inhibitor was reported in cases of severe congenital hemophilia A with HLA-DRB1*15:01, DQA1*01:02, and DQB1*06:02 alleles [8,9]. Conversely, another study reported that HLA class I alleles were not associated with the occurrence of FVIII inhibitor in patients with acquired hemophilia A, whereas $\mathrm{DRB1} * 16$ and $\mathrm{DQB1} * 0502$ were associated with a high risk of such an occurrence in hemophilia A patients with FVIII inhibitor [10]; however, the association between these alleles and FVIII inhibitor in Thai patients with hemophilia A remains unknown. As such, the present study aimed to investigate the association between HLA class II alleles and the occurrence of FVIII inhibitor in a group of Thai patients with hemophilia A.

\section{Material and Methods}

The study included 57 hemophilia A patients from Mahidol University, Faculty of Medicine Ramathibodi Hospital, Division of Hematology, Department of Pediatrics, Bangkok, Thailand, and a control group consisting of 36 unrelated male blood donors from the National Blood Center of the Thai Red Cross Society. The study protocol was approved by the Mahidol University, Faculty of Medicine Ethics Committee and the Committee on Human Rights Related to Research Involving Humans. Informed consent was obtained from each participant and/or his parents.

The patients were regularly monitored for factor VIII inhibitor every 6-12 months or when clinically indicated in cases of unresponsiveness to replacement therapy. The inhibitor titer against human factor VIII clotting activity was determined via the Bethesda method [11]. A Bethesda unit (BU) level $>0.6$ was considered indicative of the presence of inhibitor. Moreover, genetic defect associated with hemophilia A was carried out. Inversion of intron 22 was initially determined via inverse polymerase chain reaction (PCR) $[12,13]$. In patients without inversion of intron 22 conformation-sensitive gel electrophoresis was used to further investigate the genetic defect [14], followed by sequencing.

Genomic DNA was extracted from peripheral blood cells using the salting out technique [15]. The second exon of the DRBI and DQBl genes was amplified using the PCR-SSP method. Each DNA sample (100 ng $\mu \mathrm{L}^{-1}$ ) was tested using a Micro SSP Generic HLA Class II Typing Kit (One Lambda Inc., Canoga Park CA, USA). Briefly, for HLA class II low-resolution typing each DNA sample (100 ng) was amplified with 31 different primer sets optimized and dispensed into each well of a 96-well thin-walled PCR plate. The SSP-DNA reaction set was placed in a G-STORM GS1 thermal cycler (Gene Technologies Ltd., Essex, UK). The cycle parameters of the PCR program were set according to the manufacturer's instructions. The reaction pattern was photographed and HLA alleles were assessed via 
analysis of the gel banding pattern using a reaction pattern typing grid.

The association of the HLA class II alleles and the development of an inhibitor in Thai patients with hemophilia A was calculated using the odds ratio (OR) and 95\% confidence interval (CI). The frequency of alleles in the patients and controls was compared using chi-square contingency table analysis with Yates' correction, as well as standard $\mathrm{P}$ values and Fisher's exact test. A P value $<0.05$ was accepted as statistically significant.

\section{Results}

The study included 57 male Thai hemophilia A patients with a mean age of $14.4 \pm 8.9$ years. The patients were divided into 2 groups: 26 patients without inhibitors and 31 patients with a high inhibitor titer $\geq 5 \mathrm{BU}(\mathrm{n}=22)$, low inhibitor titer $<5 \mathrm{BU}(\mathrm{n}=3)$, and transient low inhibitor titer for $<6$ months $(n=6)$. The mean high inhibitor titer was $540.9 \mathrm{BU}$ (range: 5.3-3920 BU) and the mean low titer was 3.3 BU (range: 2.9-4.2 BU), whereas the mean transient low titer was 2.0 BU (range: 1.0-3.3 BU).

A molecular defect related to the factor VIII gene was observed in 35 of the 57 patients (61.4\%) of which 15 were in the non-inhibitor group and 20 were in the inhibitor group. In all, 6 patients in the non-inhibitor group and 12 patients in the inhibitor group had inversion of intron 22: however, the difference in the number of patients with inversion between the patients with and without inhibitor was not statistically significant $(P=0.32)$. The specific mutations were investigated in the 17 patients without inversion of intron 22; 10 patients had point mutations and mutations could not be identified in the other 7 patients. Interestingly, point mutations inducing stop codon ( $n=2)$, amino acid alteration $(n=2)$, and frameshift mutation $(n=1)$ were observed in patients without inhibitor, and point mutations inducing stop codon ( $\mathrm{n}=$ 5) were noted in patients with inhibitor. The occurrence of stop codon in patients with inhibitor was higher than those without inhibitor $(P=0.05)$.

The distribution of HLA-DRB1 and DQB1 alleles, according to PCR-SSP low-resolution typing, in the patients with and without inhibitor, and in the controls is shown in Tables 1 and 2. Overall, 13 DRB1 alleles were noted in the hemophilia A patients, of which DRB1*15 and DRB1*12 were the most frequent; additionally, $7 \mathrm{DQB1}$ alleles were identified. The most common DQB1 alleles in the patients

Table 1: Distribution of HLA-DRB1 Alleles in the Thai Hemophilia A Patients and Controls

\begin{tabular}{|c|c|c|c|c|c|c|}
\hline \multirow{2}{*}{ DRB1 allele } & \multicolumn{2}{|c|}{$\begin{array}{l}\text { Hemophilia A without } \\
\text { inhibitor }(\mathrm{n}=26)\end{array}$} & \multicolumn{2}{|c|}{$\begin{array}{l}\text { Hemophilia A with inhibitor } \\
\qquad(\mathrm{n}=31)\end{array}$} & \multicolumn{2}{|c|}{ Controls $(n=36)$} \\
\hline & Observed & $\%$ & Observed & $\%$ & Observed & $\%$ \\
\hline $\mathrm{DRB}{ }^{*} 01$ & 1 & 1.9 & 0 & 0.0 & 1 & 1.4 \\
\hline $\mathrm{DRBl}^{*} 03$ & 2 & 3.8 & 1 & 1.6 & 5 & 6.9 \\
\hline $\mathrm{DRB} 1 * 04$ & 5 & 9.6 & 6 & 9.7 & 10 & 13.9 \\
\hline $\mathrm{DRB}{ }^{*} 07$ & 5 & 9.6 & 3 & 4.8 & 10 & 13.9 \\
\hline $\mathrm{DRB} 1 * 08$ & 4 & 7.7 & 0 & 0.0 & 6 & 8.3 \\
\hline DRB1*09 & 5 & 9.6 & 6 & 9.7 & 3 & 4.2 \\
\hline $\mathrm{DRB}^{*} 10$ & 0 & 0.0 & 1 & 1.6 & 2 & 2.8 \\
\hline $\mathrm{DRBl}^{*} 11$ & 4 & 7.7 & 2 & 3.2 & 4 & 5.6 \\
\hline $\mathrm{DRBl}^{*} 12$ & 7 & 13.5 & 13 & 21.0 & 8 & 11.1 \\
\hline $\mathrm{DRBl}^{*} 13$ & 1 & 1.9 & 5 & 8.1 & 4 & 5.6 \\
\hline $\mathrm{DRB} 1 * 14$ & 8 & 15.4 & 4 & 6.5 & 6 & 8.3 \\
\hline $\mathrm{DRBI}^{*} 15$ & 10 & 19.2 & 19 & $30.6^{* *}$ & 10 & 13.9 \\
\hline $\mathrm{DRB}^{*} 16$ & 0 & 0.0 & 2 & 3.2 & 3 & 4.2 \\
\hline
\end{tabular}

${ }^{* *} P=0.021 ; O R=2.74 ; 95 \% C I=1.16-6.47$. 
Table 2: Distribution of HLA-DQB1 Alleles in the Thai Hemophilia A Patients and Controls

\begin{tabular}{|c|c|c|c|c|c|c|}
\hline \multirow[t]{2}{*}{ DQB1 allele } & \multicolumn{2}{|c|}{$\begin{array}{l}\text { Hemophilia A without } \\
\text { inhibitor } \\
(\mathrm{n}=26)\end{array}$} & \multicolumn{2}{|c|}{$\begin{array}{l}\text { Hemophilia A with } \\
\text { inhibitor } \\
(\mathbf{n}=31)\end{array}$} & \multicolumn{2}{|c|}{$\begin{array}{l}\text { Controls } \\
(n=36)\end{array}$} \\
\hline & Observed & $\%$ & Observed & $\%$ & Observed & $\%$ \\
\hline DQB1*05 & 18 & 34.6 & 22 & 35.5 & 19 & 26.4 \\
\hline $\mathrm{DQB1}{ }^{*} 06$ & 7 & 13.5 & 10 & 16.1 & 11 & 15.3 \\
\hline $\mathrm{DQB1}{ }^{*} 02$ & 7 & 13.5 & 3 & 4.8 & 13 & 18.1 \\
\hline DQB1*03:01/:04 & 9 & 17.3 & 14 & 22.6 & 13 & 18.1 \\
\hline DQB1*03:02/:05/:07 & 3 & 5.8 & 2 & 3.2 & 5 & 6.9 \\
\hline DQB1*03:03:02/:06 & 5 & 9.6 & 7 & 11.3 & 6 & 8.3 \\
\hline $\mathrm{DQB1}{ }^{*} 04$ & 3 & 5.8 & 4 & 6.5 & 5 & 6.9 \\
\hline
\end{tabular}

and controls were $\mathrm{DQB1}{ }^{*} 05$ and $\mathrm{DQB1}^{*} 06$, respectively. DQB1*03 was sub-typed as $\mathrm{DQB1}^{*} 03: 01 / 03: 04$, DQB1*03:02/03:05/03:07, and DQB1*03:03:02/03:06 via PCR-SSP low-resolution typing.

The frequency of $\mathrm{DRB} 1 * 15$ was higher in the patients (both with and without inhibitor) than in the controls, however, statistical significance was found between patients with inhibitor and the controls $(30.6 \%$ vs. $13.9 \% ; \mathrm{P}=0.021 ; \mathrm{OR}=2.74 ; 95 \% \mathrm{CI}=1.16-6.47)$. The frequency of DRB1*15 in the patients with FVIII inhibitor $(30.6 \%)$ was higher than that in the patients without inhibitor (19.2\%), but the difference was not statistically significant $(\mathrm{P}=0.198)$. On the other hand, the frequency of $\mathrm{DRB1}^{*} 14, \mathrm{DRB1}^{*} 07$, and $\mathrm{DQB1}{ }^{*} 02$ was lower in the patients with inhibitor than in those without inhibitor ( $P$ $>0.05)$.

\section{Discussion}

Both genetic and non-genetic risk factors have been implicated in the development of factor VIII inhibitor $[16,17]$. The molecular defects in the FVIII gene that cause a defect in translation and protein production is a primary cause of inhibitor formation. Polymorphisms associated with HLA class II molecules, interleukin-10 (IL-10), and tumor necrosis factor- $\alpha$ (TNF- $\alpha$ ) also influence to the FVIII inhibitor development [18]. Immunological mechanisms in the cellular processing of peptide antigens are involved in the development of inhibitor in patients with hemophilia A. Moreover, the major histocompatibility complex phenotype is also involved in inhibitor formation [19-21].
Although a molecular defect associated with factor VIII was observed in 35 of the 57 patients in the present study, inversion of intron 22 was observed in more of the patients with inhibitor than in those without inhibitor, as previously reported [22,23]; however, the frequency of point mutations causing stop codon in patients with inhibitor was significantly higher than in those without inhibitor, which was also previously reported [24]. Moreover, the association between HLA class II alleles and the FVIII inhibitors in Thai hemophilia patients was further investigated in this study, as recent studies have indicated that inhibitor formation depends upon an adequate T-cell response by major histocompatibility complex class II molecules to FVIII resulting from the presentation of FVIII protein antigen to T-cell receptors [18-21]. It was reported that in mild hemophilia A patients with inhibitor the frequency of $\mathrm{DRB1}^{*} 01$ and $\mathrm{DQB1}{ }^{*} 05$ was slightly higher than the controls (but not significantly) [25]. A comparison of the frequency data for DRB1*15/16 in hemophilia A patients with FVIII inhibitor reported in other studies showed that DRB1*15 and DRB1*16 were high-risk alleles for inhibitor formation in patients with congenital hemophilia A and acquired hemophilia A, respectively [8-10].

The DRB1*15 allele is known to exhibit the specific surface loop peptide comprising amino acids 1706-1721 of the FVIII light chain, and is considered to be involved in FVIII inhibitor formation in patients with congenital hemophilia A that lack endogenous FVIII protein synthesis $[8,26]$. Because the ability to recognize and process FVIII peptides is determined by the number of HLA class II molecules in each individual. It was reported that 
there are as many as 13 potential recognition sequences for HLA-DRB1*1501 in FVIII, whereas there are only 2 recognition sequences for HLA-DRB1*1101 [27]. Even though HLA-DRB1*15 (17.5\%), DRB1*12 (16.9\%), and DRB1*09 (11.5\%) were the most common in Thai blood donors [28], the frequency of the DRB1* 15 allele among hemophilia A patients with inhibitors in the present study was significantly higher than in the controls.

Limitations of the present study included the small number of patients enrolled, incomplete detection of molecular defects of the factor VIII gene, and the lack of exploration of the polymorphisms associated with IL-10 and TNF- $\alpha$. In conclusion, the DRB1*15 allele may have contributed to inhibitor formation in Thai patients with hemophilia A. Additional comprehensive research with larger patient populations is warranted.

\section{Conflict of Interest Statement}

The authors of this paper have no conflicts of interest, including specific financial interests, relationships, and/ or affiliations relevant to the subject matter or materials included.

\section{Acknowledgements}

This study was supported by the Thailand Research Fund: Senior Research Scholar 2006 (AC).

\section{References}

1. Wight J, Paisley S: The epidemiology of inhibitors in haemophilia A: A systemic review. Haemophilia 2003; 9: 418-435

2. Addiego J, Kasper C, Abildgaard C, Hilgartner M, Lusher J, Glader B, Aledort L: Frequency of inhibitor development in haemophiliacs treated with low-purity factor VIII. Lancet 1993; 342: 462-464

3. Mahasandana C, Patharathienskul D, Suvatte V: Hemophilia with factor VIII and IX inhibitors, incidence, bleeding problems and management. Southeast Asian J Trop Med Public Health 1993; 24 (Suppl1): 106-112

4. Bray GL, Gomperts ED, Courter S, Gruppo R, Gordon EM, Manco-Johnson M, Shapiro A, Scheibel E, White G 3rd, Lee M: A multicenter study of recombinant factor VIII (Recombinate): Safety, efficacy, and inhibitor risk in previously untreated patients with hemophilia A. The Recombinate Study Group. Blood 1994; 83: 2428-2435

5. De Biasi R, Rocino A, Papa ML, Salerno E, Mastrullo L, De Blasi D: Incidence of factor VIII inhibitor development in hemophilia A patients treated with less pure plasma derived concentrates. Thromb Haemost 1994; 71: 544-547
6. Kavakli K, Gringeri A, Bader R, Nisil G, Polat A, Aydinok Y: Inhibitor development and substitution therapy in a developing country: Turkey. Haemophilia 1998; 4: 104-108

7. Wight J, Paisley S: The epidemiology of inhibitors in haemophilia A: A systematic review. Haemophilia 2003; 9: 418-435

8. Oldenburg J, Picard JK, Schwaab R, Brackmann HH, Tuddenham EG, Simpson E: HLA genotype of patients with severe haemophilia A due to intron 22 inversion with and without inhibitors of factor VIII. Thromb Haemost 1997; 77: $238-242$

9. Hay CR, Ollier W, Pepper L, Cumming A, Keeney S, Goodeve AC, Colvin BT, Hill FG, Preston FE, Peake IR: HLA class II profile: A weak determinant of factor VIII inhibitor development in severe haemophilia A. UKHCDO Inhibitor Working Party. Thromb Haemost 1997; 77: 234-237

10. Pavlova A, Zeitler H, Scharrer I, Brackmann HH, Oldenburg $\mathrm{J}$ : HLA genotype in patients with acquired haemophilia A. Haemophilia 2010; 16: 107-112

11. Kasper CK, Aledort LM, Counts RB: A more uniform measurement of factor VIII inhibitors. Thromb Diath Haemorrh 1975; 34: 869-872

12. Rossetti LC, Radic CP, Larripa IB, De Brasi CD: Developing a new generation of tests for genotyping hemophilia-causative rearrangements involving int $22 \mathrm{~h}$ and int $1 \mathrm{~h}$ hotspots in the factor VIII gene. J Thromb Haemost 2008; 6: 830-836

13. Rossetti LC, Radic CP, Larripa IB, De Brasi CD: Genotyping the hemophilia inversion hotspot by use of inverse PCR. Clin Chem 2005; 51: 1154-1158

14. Williams IJ, Abuzenadah A, Winship PR, Preston FE, Dolan G, Wright J, Peake IR, Goodeve AC: Precise carrier and prenatal diagnosis in families with haemophilia A: Use of conformation sensitive gel electrophoresis for rapid mutation screening and polymorphism analysis. Thromb Haemost 1998; 79: 723-726

15. Sasanakul W, Chuansumrit A, Rurgkhum S. Udomsubpayakul U, Hathirat P: DNA extraction and amplification of 10-day, room-temperature blood samples. J Med Assoc Thai 1999; 82 (Suppl 1): 186-189

16. Astermark J, Berntorp E, White GC, Kroner BL; The MIBS Study Group: The Malmo International Brother Study (MIBS): Further support for genetic predisposition to inhibitor development. Haemophilia 2001; 7: 267-272

17. Astermark J: Basic aspects of inhibitors to factors VIII and IX and the influence of non-genetic risk factors. Haemophilia 2006; 12 (Suppl 6): 8-14

18. Pavlova A, Delev D, Lacroix-Desmazes S, Schwaab R, Mende M, Fimmers R, Astermark J, Oldenburg J: Impact of polymorphisms of the major compatibility complex class II, interleukin-10, tumor necrosis factor-alpha and cytotoxic 
T-lymphocyte antigen-4 genes on inhibitor development in severe haemophilia A. J Thromb Haemost 2009; 7: 2006-2015

19. Singer ST, Addiego JE Jr, Reason DC, Lucas AH: T lymphocyte proliferative responses induced recombinant factor VIII in hemophilia A patients with inhibitors. Thromb Haemost 1996; 76: 17-22

20. Reding MT, Wu H, Krampf M, Okita DK, Diethelm-Okita BM, Christie BA, Key NS, Conti-Fine BM: Sensitization of CD4+ T cells to coagulation factor VIII: Response in congenital and acquired hemophilia patients and in healthy subjects. Thromb Haemost 2000; 84: 643-652

21. Jacquemin M, Vantomme V, Buhot C, Lavend'homme R, Burny W, Demotte N, Chaux P, Peerlinck K, Vermylen J, Maillere B, van der Bruggen P, Saint-Remy JM: CD4+ T-cell clones specific for wild-type factor VIII: A molecular mechanism responsible for a higher incidence of inhibitor formation in mild/moderate hemophilia A. Blood 2003; 101: 1351-1358

22. Schwaab R, Brackmann HH, Meyer C, Seehafer J, Kirchgesser M, Haack A, Olek K, Tuddenham EG, Oldenburg J: Haemophilia A mutation type determines risk of inhibitor formation. Thromb Haemost 1995; 74: 1402-1406

23. Tuddenhamn EG, McVey JH: Genetic basis of inhibitor development in haemophilia A. Haemophilia 1998; 4: 543-545

24. Antonarakis SE, Rossiter JP, Young M, Horst J, de Moerloose P, Sommer SS, Ketterling RP, Kazazian HH Jr, Négrier C, Vinciguerra C, Gitschier J, Goossens M, Girodon E, Ghanem N, Plassa F, Lavergne JM, Vidaud M, Costa JM, Laurian Y, Lin SW, Lin SR, Shen MC, Lillicrap D, Taylor SA, Windsor S, Valleix SV, Nafa K, Sultan Y, Delpech M, Vnencak-Jones CL, Phillips JA 3rd, Ljung RC, Koumbarelis E, Gialeraki A, Mandalaki T, Jenkins PV, Collins PW, Pasi KJ, Goodeve A, Peake I, Preston FE, Schwartz M, Scheibel E, Ingerslev J, Cooper DN, Millar DS, Kakkar VV, Giannelli F, Naylor JA, Tizzano EF, Baiget M, Domenech M, Altisent C, Tusell J, Beneyto M, Lorenzo JI, Gaucher C, Mazurier C, Peerlinck K, Matthijs G, Cassiman JJ, Vermylen J, Mori PG, Acquila M, Caprino D, Inaba H.: Factor VIII gene inversions in severe hemophilia A. Results of an international consortium study. Blood 1995; 86: 2206-2212
25. Bril WS, MacLean PE, Kaijen PH, van den Brink EN, Lardy NM, Fijnvandraat K, Peters M, Voorberg J: HLA class II genotype and factor VIII inhibitors in mild haemophilia A patients with an Arg 593 to Cys mutation. Haemophilia 2004; 10: 509-514

26. Chicz RM, Urban RG, Gorga JC, Vignali DA, Lane WS, Strominger JL: Specificity and promiscuity among naturally processed peptides bound to HLA-DR alleles. J Exp Med 1993; 178 27-47

27. White GC 2nd, Kempton CL, Grimsley A, Nielsen B, Roberts HR: Cellular immune responses in hemophilia: Why do inhibitors develop in some, but not all hemophiliacs? J Thromb Haemost 2005; 3: 1676-1681

28. Kupatawintu P, Pheancharoen S, Srisuddee A, Tanaka H, Tadokoro K, Nathalang O: HLA-A, -B, -DR haplotype frequencies in the Thai stem cell donor registry. Tissue Antigens 2010; 75: 730-736 